\title{
The Relationship Of Family Support With Blood Sugar Levels In Clients With Diabetes Mellitus Type 2 In Poly Diseases In Blud Rsud Dr. Doris Sylvanus Palangka Raya
}

\author{
Natalansyah \\ Program Of Study Bachelor Of Applied Keperawatan Poltekkes Kemenkes Palangka Raya, Indonesia. \\ ${ }^{*}$ Corresponding author: \\ Email: tatathomas268@gmail.com
}

\begin{abstract}
.
International Diabetes Federation (IDF) estimates that there is an increase in the number of people with diabetes in Indonesia from 9.1 million in 2014 to 14.1 million in 2035. Type 2 diabetes is the most common type. Diabetes is a group of metabolic diseases characterized by hyperglycemia due to defects in insulin secretion, insulin action, or both. Diabetes mellitus can cause various physical or psychological changes or disorders for clients where they must depend on diabetes management therapy. The purpose of this study was to determine the relationship of stress levels with self-care to clients of type 2 diabetes mellitus at the Internal Medicine Poly Blud Rsud dr. Doris Sylvanus. This study used a crosssectional study design, with a purposive sampling technique, the number of samples in this study were 35 respondents, collecting data using the Summary questionnaire The Summary of Diabetes Self-Care Activities (SDSCA and Diabetes Distress Scale (DSS) and analyzed using a test chi-square The results of this study indicate that of the 20 respondents who were severely stressed 18 respondents were not good at self-care and of the 15 respondents who experienced mild stress 10 respondents were able to perform self-care well. In the chisquare test results obtained $p$-value $=0.001$, where the value of $p<\alpha(\alpha=0.05)$ can be concluded that there is a significant relationship between stress levels and self-care were the higher the level of stress, the lower the self-care behavior.
\end{abstract}

Keywords: Diabetes Melitus, Family Support, Blood Sugar Levels

\section{INTRODUCTION}

According to the World Health Organization (WHO), deaths from non-Communicable Diseases (PTM) is expected to continue to increase around the world, the largest increase will occur in the countries of the middle and poor. More than two-thirds $(70 \%)$ of the global population will die from the disease is not contagious. One of the non-communicable diseases is diabetes mellitus (DM). DM is a disease of metabolic disorders chronic due to the pancreas not producing enough insulin or the body cannot use the insulin produced effectively ( Kemenkes RI, 2018).WHO estimates that globally, 422 million adults aged $>18$ years living with diabetes. Number of people with diabetes has increased in the last decades, due to population growth increasing age, and the increase in the prevalence of diabetes of any age (WHO, 2016). International Diabetes Federation (IDF) estimates the increase in the number of people with DM in Indonesia from 9.1 Million in 2014 to 14.1 Million in the year 2035. Type 2 DM is the most common type to occur, and has increased with culture and social change, about 90\% of all diabetes cases are type 2 (IDF Atlas ,2017:18). In 2015, Indonesia ranked seventh in the world for the prevalence of diabetes is highest in the world along with China, India, the United States, Brazil, Russia and mexico with the estimated number of people with diabetes by 10 Million (IDF Atlas, 2015). The prevalence of people with diabetes in Indonesia showed an increase iefrom the year 2007 by $5.7 \%$ to $6.9 \%$ in 2013 (Riskesdas, 2018). Based on the medical record notes BLUD RSUD dr. Doris Sylvanus cases of diabetes mellitus non insulin-dependent on the Installation of Outpatient Poly Diseases In the year 2017 as much as 4.942 the case where the number of women 2.759 more than in men 2.183. (RM.RSUD DS, 2018)Diabetes Mellitus can cause a variety of changes to or disorders of physical and psychological harm to the client where they should depend on the therapeutic management of diabetes. Must patients with diabetes mellitus change the pattern of life so that the blood sugar in the body remains balanced diet can result in them vulnerable to stress, because stress will occur when a person perceives the presence of a mismatch between the resources with the demands of the situation that must be executed, when the demands of the situation felt different with the previous situation and is too heavy then the stress will happen.

Stress is a disturbance in the body and mind caused by the demands of life. (Irfan, 2015).Vranić et al. (2000) mention stress in patients with Diabetes Mellitus can result in disturbances in the control of blood sugar levels. Furthermore, Atiq ur Rehman, 2015 says that in the course of the disease a person with diabetes should depend on the therapeutic management of diabetes to cope with changes in physical or pikologis. A similar study also conducted by Rehman (2015) in Loriza, et al (2017:313) of 240 patients with type 2 Diabetes showed that experiencing stress $69,2 \%$. Elpriska (2016:22) states on the state of stress will be an increase in hormones 
and have an impact on the decrease in endurance type 2 DM patients, so it will be easy to experience health problems. The impact of both physical and psychological certainly will continue to decline in the ability to do self-care. The stress associated with a decrease in the ability of individuals to do the treatment itself. Clients who are experiencing stress, have the motivation and self-management are the ability to control blood sugar less. The results of the Research Helme (2004) and the Legman (2005) in the Gillani (2012:538-539) mentions that only about $7-25 \%$ of persons with DM obedient to all aspects of the behavior of self-care. About $40-60 \%$ failure diet, $30-80 \%$ not obedient to the control of blood sugar and 70-80\% were not adherent to the sport. Research Kusniawati (2011:90) get that the average patient with DM do self-care of diabetes was 4.9 days in a week, this study shows that the client DM has yet to implement self-care in full 7 days in a week.

\section{RESEARCH METHODS}

\section{Research Design}

This research is research that is correlation by using a study design descriptive cross-sectional design using a cross-sectional study through a survey that observes an object of research both one and several variables, by way of collecting data at a time.

\section{Sample and Sampling}

The sample in this study were 35 respondents in Poly Diseases In BLUD RSUD dr. Dorys Sylvanus Palangka Raya by using purposive sampling.

\section{Research Instruments}

The research instrument is a tool for researchers is a questionnaire of Family Support and examination of the blood sugar levels of the client with diabetes mellitus type 2

\section{Data Analysis}

Data analysis used is univariate analysis that is described by the value and number of percentage support and blood sugar levels, and this Study using Chi-Square test type table $2 \times 2$.

\section{RESULTS AND DISCUSSION}

Table 1. The Frequency distribution of Family Support On a Client with Type II Diabetes at the internal Diseases section Blud Rsud dr. Doris Sylvanus Palangka Raya

\begin{tabular}{lcc}
\hline \multicolumn{1}{c}{ Family support } & Frequency (f) & Percentage (\%) \\
\hline Good & 11 & 31,4 \\
Less Is Better & 24 & 68,6 \\
Total & 35 & 100,0 \\
\hline
\end{tabular}

The table above shows that most of the family support clients with Type II Diabetes at the internal Diseases section BLUD RSUD dr. Doris Sylvanus in the unfavorable category as many as 24 people $(68,6 \%)$. Family support can be addressed with the involvement of the nurse in providing support to family members both during the patient undergoing treatment and provide information to patients that family support is very important in the process of treatment in accordance with the schedule and still have the spirit in living aktivas day-to-day. Different results with the research done (Yuanita Wijayanti, 2015) stated that family support can help people with diabetes mellitus type two in the continuing life. With the support of the family, people with diabetes mellitus type two is to feel loved, still needed by the family and his life is still valuable to others, including to his family.

Table 2. Frequency Distribution Aspects of Family Support On a Client with Type II Diabetes at the internal Diseases section BLUD RSUD dr. Doris Sylvanus Palangka Raya .

\begin{tabular}{lcc}
\hline Family support & $\begin{array}{c}\text { Frequency } \\
\text { (f) }\end{array}$ & $\begin{array}{c}\text { Percentage } \\
(\%)\end{array}$ \\
\hline Encouragement Emotionally & 15 & $42,9 \%$ \\
Good & 20 & $57,1 \%$ \\
Less Is Better & 12 & $34,3 \%$ \\
Encouragement Award & 23 & $65,7 \%$ \\
Good & & \\
Less Is Better & 17 & $48,6 \%$ \\
Information Encouragement & 18 & $51,4 \%$ \\
Good & & \\
Less Is Better & 15 & $42,9 \%$ \\
Intrumental Encouragement & 20 & $57,1 \%$ \\
Good & & \\
Less Is Better & & \\
\hline
\end{tabular}


Based on table 2 it can be seen the support of the family at the internal Diseases section BLUD RSUD dr. Doris Sylvanus, family support less good many more that aspects of emotional support as many as 20 people (the $57.1 \%$ ), support of the award as many as 23 people $(65,7 \%)$, information support as many as 18 people $(51,4 \%)$ and instrumental support as many as 20 people (the $57.1 \%)$. The results of this study in accordance with the Rasaningtyas (2012) note that the 24 people (61,5\%) family support which is lacking in the form of attention and emotion, 30 (76,9\%) family support which is lacking in the form of assistance instrumental 29 people $(74,4 \%)$ family support which is lacking in the form of the provision of information, 39 people (100\%) family support which is lacking in the form of ratings and 27 people $(69,2 \%)$ family support which is lacking in the form of the award, preferably the support that can be applied in providing motivation that is motivated by the identification of (motivating by identification on egoinvoiremen), namely how to motivate to instill awareness. Family support is the support that is given by a family consisting of the above information or advice verbal and non-verbal real help or action given by the familiarity of social and obtained due to the presence of them and has the benefits of emotional or behavioral effects for the receiving party (Gottieb, 1983, quoted Smet, 1994, in Nursalam \& Kurniawati 2007).

Table 3. The Frequency distribution of Blood Sugar Levels on a Client with Type II Diabetes at the internal Diseases section BLUD RSUD dr. Doris Sylvanus Palangka Raya.

\begin{tabular}{lcc}
\hline Blood Sugar Levels & Frequency (f) & Percentage (\%) \\
\hline Normal & 12 & 34,3 \\
High & 23 & 65,7 \\
\hline Total & 35 & 100,0 \\
\hline
\end{tabular}

Table 3. the above shows that the results of research conducted on 35 respondents in Poly Diseases In BLUD RSUD dr. Doris Sylvanus Palangka Raya shows that most respondents have a category of high blood sugar levels as much as 23 respondents (65.7\%), compared to the normal category as many as 12 respondents $(34,3 \%)$. This research is in line with research conducted by Atyanti, (2008), in his research with the use of the 166 people get the results of the 94 respondents $(56,6 \%)$ have high blood sugar levels, and 72 respondents $(43,4 \%)$ have normal blood sugar levels. The observations made at the time of research, this is because most of the respondents rarely do the checks blood sugar levels regularly and just do the examination in the centre of the health service.

Table 4. The relationship of family support with blood sugar levels on a client with type 2 Diabetes in Poly Diseases In BLUD RSUD dr. Doris Sylvanus Palangka Raya

\begin{tabular}{lllllll}
\hline Blood Sugar levels & Normal & $\%$ & High & $\%$ & $\begin{array}{l}\text { Total } \\
\%\end{array}$ & P Value \\
\hline Family support & & $72,7 \%$ & 3 & $27,3 \%$ & $100,0 \%$ & \\
Good & 8 & $16,7 \%$ & 20 & $83,3 \%$ & $100,0 \%$ & 0,001 \\
Less Is Better & 4 & $34,3 \%$ & 23 & $65,7 \%$ & $100,0 \%$ & \\
\hline \multicolumn{1}{c}{ Total } & 12 & & &
\end{tabular}

The results of this study show that there is a significant relationship between family support with blood sugar levels, which the respondents who have good family support with normal blood sugar levels 8 respondents $(72,7 \%)$, and respondents who have a good family support with high blood sugar levels that 3 respondents (of $27.3 \%$ ), then respondents who have family support that are less well with normal blood sugar levels that 4 respondents (16.7\%), and respondents who have family support less well with high blood sugar levels as many as 20 respondents $(83,3 \%)$ with p value of $0.001(L=0,05)$. This research shows the less good family support on the client DM, the higher the blood sugar levels on the client that, from the results of the research can be concluded that family support in patients with DM Type 2 in Poly Diseases In BLUD RSUD dr. Doris Sylvanus Palangka Raya in the unfavorable category. Research on family support blood sugar levels are still many who have family support and high blood sugar levels, so that the education of health and the interpersonal approach should be carried out by the closest family members.Family support can help patients with diabetes mellitus to cultivate the motivation to do the treatment. Family support that is given can be in the form of attention by emotion with the willingness of the family to accompany the patient undergoing treatment. Family support is needed by patients with diabetes mellitus when treatment with a soothing liver of the patient that the family would get together and help the patient in the treatment process. This is in accordance with According to Ratna (2010), family support is an important Factor of a person when faced with a problem (health) and as a preventive strategies to reduce stress where outlook on life became widespread and not easily stressed. There is strong support between families and the health status of its members where family is very important to every aspect of care, health care members of his family to achieve a healthy state to the optimum level. 


\section{CONCLUSION AND SUGGESTIONS \\ Conclusion}

Based on the results of this research it is known that there is a significant relationship between family support with blood sugar levels on a client with Type 2 DIABETES with p-value $0.001(\llcorner=0,05)$, where the poor family support, the higher the blood sugar levels in these patients.

\section{Suggestions}

1.Health institution consisting of the nursing profession and other health workers is expected to provide motivation, intervention, and health education more related the importance of family support diabetic patients in improving health status and quality of life of the client.

2.Need improved knowledge and skills of the nurse who handles clients of DM in Hospital

\section{REFERENCES}

[1] Atyanti I. 2008. Hubungan depresi dan dukungan keluarga keluarga terhadap kadar gula darah pada pasien diabetes melitus tipe 2 di RSUD Sragen.

[2] BLUD RSUD Dorys Silvanus Palangka Raya, 2018, Rekam Medis Poli Penyakit dalam

[3] Chusmeywati Vitta.2016. Hubungan Dukungan Keluarga Terhadap Kualitas Hidup Penderita Diabetes Melitus di RS PKU Muhammadiyah Yogyakarta Unit II. Info Pada Tanggal 15 Desember 2018

[4] Elpriska, 2016 Pengaruh stres, dukungan keluarga dan manajemen diri terhadap komplikasi ulkus kaki diabetik pada penderita dm tipe 2

[5] Gillani, 2012 Pharmacist Intervention in home care program for diabetes patients, Journal of diabetes mellitus, Volume 2 (3)

[6] Irfan.2015. Hubungan Tingkat Stres Dengan Kadar Gula Darah Pada Penderita Diabetes Melitus (DM) Di Puskesmas Peterongan Kabupaten Jombang. di akses 9 januari 2019

[7] Kemenkes RI, 2018 Infodatin Pusat Data dan Informasi tentang Diabetes mellitus, Jakarta

[8] Kusniawati., 2011. Analisis Faktor yang Berkontribusi terhadap Self Care Diabetes pada Klien Diabetes Melitus Tipe 2 di Rumah Sakit Umum Tangerang.Tesis. Depok: Universitas Indonesia.

[9] Loriza Sativa Yan,Rara Marisdayana, Rizki Irma OR, 2017 hubungan penerimaan diri dan tingkat stres pada penderita diabetes mellitus, STIKES Harapan Ibu Jambi

[10] Nursalam, Kurniawati D. N. (2007). ... Hubungan antara dukungan keluarga dan kualitas hidup pasien DM tipe 2 di Poliklinik Penyakit Dalam Rumah sakit

[11] Nurrokhmah, 2014 Efektivitas Pelatihan relaksasi untuk Menurunkan stres penderita Diabetes mellitus tipe 2 program pendidikan magister profesi psikologi Fakultas psikologi Universitas muhammadiyah surakarta

[12] Rachmawati Nita. 2015. Gambaran Kontrol Dan Kadar Gula Darah Pada Pasien Diabetes Melitus Di Poliklinik Penyakit Dalam RSJ Prof. Dr. Soerojo Magelang. Diakses tanggal 15 Desember 2018.

[13] Ratna, W. (2010). Sosiologi dan antropologi kesehatan. Yogyakarta: Pustaka Rihama.

[14] Riskesdas.2018. Riset Kesehatan Dasar. Diunduhtanggal 15 Desember 2018

[15] Vranic, M.: Lickley, H.L.A. \& Davidson, J.K (2000). Exercise and Stress in Diabetes Mellitus dalam J.K. Davidson (ed.) Clinikal Diabetes Mellitus: A Problem Oriented Approach. New York, Thieme Verlag Inc. pp.

[16] World Health Organization.2016.Global Report on Diabetes. Di unduh tanggal 18 Desember 2018

[17] Yuanita Wijayanti. 2015. Dukungan keluarga bagi penderita diabetes melitus tipe dua. Diakses 29 april 2019 